\title{
Vegetarianism and Virtue: On Gassendi's Epicurean Defense ${ }^{1}$
}

\author{
Emily Michael \\ Brooklyn College
}

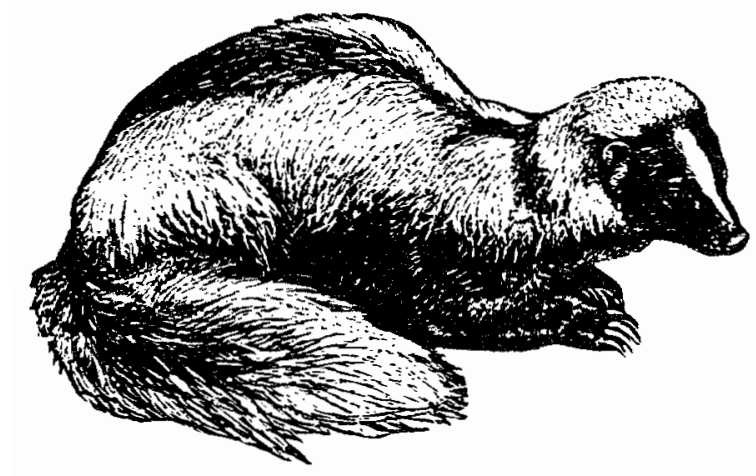

I

Gassendi, who was influenced in the development of his moral theory by Epicurus, ${ }^{2}$ was, as was Epicurus, a vegetarian. Gassendi argues, in his Philosophiae Epicuri Syntagma, ${ }^{3}$ his reconstruction of Epicurus' theory, and in his Syntagma Philosophicum, ${ }^{4}$ presenting his own ethics, that abstaining from flesh is a moral requirement, i.e., $a$ requirement for "doing well." Further, Gassendi represents, as an Epicurean position, the view that rights and the obligations attendant upon rights pertain only to those bound together by a social contract, and, agreements with animals being infeasible, we have no obligations which follow from their rights. Why and how, then, is vegetarianism a moral requirement? In what follows, I will examine a Gassendist response to this question to ascertain how vegetarianism can be supported in the context of a Gassendist moral theory.

Bernier's Abregé de la Philosophie de Gassendi (Lyons, 1684), which is an abridgement and translation into French of Gassendi's lengthy Latin Syntagma Philosophicum, served to popularize Gassendi's views. Bernier provides a reasonably faithful rendition of

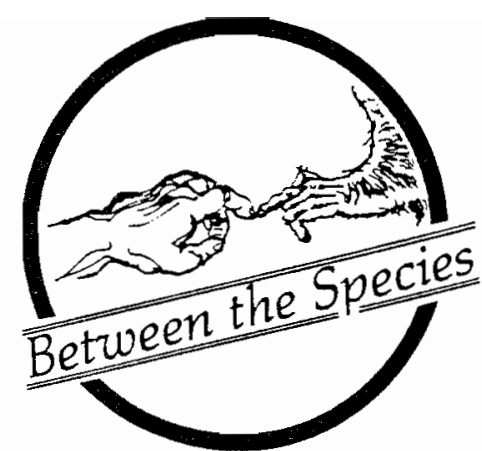

Gassendi's views. It is Bernier's text that is translated into English in Three Discourses of Happiness, Virtue and Liberty, a 1699 publication on moral philosophy that is attributed to Gassendi. ${ }^{6}$ To better comprehend the views of Gassendi as understood by seventeenthcentury Gassendists, in what follows, English translations of passages presenting Gassendi's view will, where possible, be taken from Three Discourses on Happiness, Virtue and Liberty. ${ }^{7}$ Likewise, English translations of passages from Gassendi's representation of Epicurus' view will be taken from Thomas Stanley's translation of Gassendi's Philosophiae Epicuri Syntagma. ${ }^{8}$

In the context of Gassendi's virtue ethics, in which he defines moral philosophy as "the art of doing well" $[\mathrm{TD}, 2],{ }^{9}$ Gassendi discusses the fundamental virtues of temperance, fortitude, justice, and prudence, with happiness as the summum bonum. Vegetarianism is said to be a requirement of sobriety, a virtue of temperance. He explains:

It is therefore an undeniable truth, that happiness, or a life free from pain and misery, are such things as influence all our actions and purposes to the obtaining of them. [TD, 1]

Following Epicurus, Gassendi identifies happiness with pleasure, and pleasure, he claims, is to be correctly

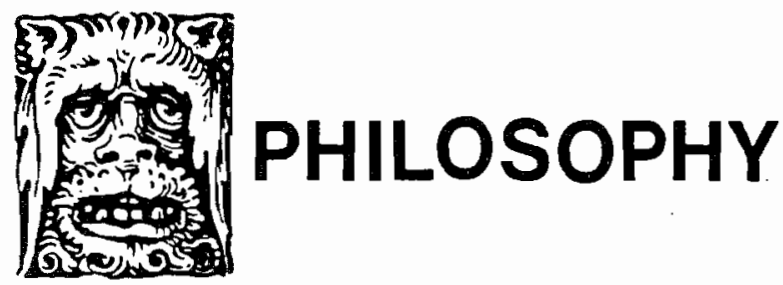


analyzed as the "relief from" or "absence of" pain or misery. [G, 2.415] Pain, from this viewpoint, is a priori undesirable and, in itself, bad. The good, as pleasure, is measured by the extent to which an action retains an absence of pain or relieves pain without producing additional pains.

Gassendi's moral theory, then, can be said to involve the following principle, which I shall refer to as "the principle of least pain": "Living well" consists in doing that which will be most effective in minimizing pain in one's own body and mind. Though pleasure associated with excessive and sumptuous eating satisfies hunger, unlike moderate eating, it bears with itself pains, and hence, this action is not a good. Sobriety is essential to living well.

In regard to diet, the following principle is required to satisfy the principle of least pain: Act only on desires for that which is both natural and necessary. That which is both natural and necessary, we are told, will relieve hunger and its associated pains without producing new pains; but a variety of discomforts follow from the consumption of that which is unnecessary or unnatural, and, hence, these should be avoided. Further, Gassendi contends in support of his vegetarianism, the consumption of flesh is neither natural nor necessary for human beings. What he means by "necessary" and "natural" requires clarification.

That which is necessary, according to Gassendi, is the minimum required, in quantity and effort, to maintain one's health and well-being. He argues (TD, 147ff.]:

1. Very little is required to satisfy basic needs and to maintain a healthy body, and these needs can be satisfied with little effort, and, hence, without pain.

2. Excesses, beyond what is physically necessary to maintain the body, can produce various sorts of pains, and such luxuries are often difficult to obtain.

3. Therefore the best way to avoid pain is to avoid the desire for excesses and to be content with a little.

Being content with a little, he contends, is the most effective way to satisfy the principle of least pain; the way to avoid pain and suffering is not by striving to acquire more, but rather by desiring less.
Gassendi represents this as Epicurus' view:

To accustom ourselves to a simple diet brings and preserves health. For it is sumptuous feasting and variety of meats which [causes] head-aches, rheums, gouts, fevers and other diseases; not plain and simple food. (SPE, 917]

Further, desiring the minimum required to maintain one's health and well-being "renders us fearless of fortune" for:

$[\mathrm{H}] \mathrm{e}$, who is content with coarse food, as fruits and salads, who is satisfied with bread and water, who has confined his desire with these, what can he fear from Fortune? For, who is there so poor as to want these? Who so distressed that he cannot easily meet with beans, pulse, herbs, fruits? As for water, what need I mention it? [SPE, 918]

A simple diet, simple in its substance and in its accessibility, contributes to a state of equilibrium of mind and body, which, if established, allows for activities which are satisfying in themselves, such as the experience of pure pleasures, e.g., of philosophy and of music, which are free of pain.

To demonstrate that flesh is not necessary for the health of human beings, Gassendi concurs with the Epicurean claim that "the eating of flesh is less to be approved, as being rather prejudicial to health than wholesome" [SPE, 918] because:

\section{[H]ealth is preserved by the same means whereby it is recovered; but it is manifest that it is recovered by $a$ thin diet and abstinence fromflesh. [SPE, 918]}

If health can be recovered, indeed is best recovered, by means of a diet that contains no flesh, then, it is argued, health can also be preserved without eating flesh, so flesh foods are not necessary for human health. As such, eating flesh is an excess, and, like other excesses, it is an indulgence that can cause pain. Further, it is assumed that flesh foods are more difficult to obtain and to prepare than "fruits and salads," "bread and water"; in desiring flesh, then, we become more subject to the difficulties associated with seeking to obtain such foods. 
It might be objected that Gassendi's assumptions are overhasty. Consider the following society of the isolated and unknown island Isla, encircled and cut off from the sea by huge rocky cliffs. On Isla the soil is such that no trees and no crops other than grass will grow. How Isla came to be inhabited is not our problem here, but on Isla there are, in fact, many animals who eat the grass as well as others, including humans, who prey on these. The human inhabitants of Isla find it easy to obtain flesh foods and to prepare these in simple ways, easier than their counterparts elsewhere find the obtaining of ingredients for and the preparation of bread. Finally, they have found it helpful, when ill, to imbibe certain boiled meats or a clear meat broth. Gassendi's arguments for vegetarianism would support the eating of flesh on Isla. Therefore, it would seem, his arguments support not vegetarianism as such, but rather a spare and simply prepared diet of whatever nutritious foods are readily available.

Gassendi, though, would reject this result, because he would claim that the inhabitants of our hypothetical island Isla are in a hardship situation that conflicts with what is natural for human beings. He claims:

The best and only remedy to pass our lives free and void of trouble, is to suit ourselves to nature, to desire nothing but what it requires.... [TD, 18]

and

[A]ccording to our natural inclination, we must love these things and make them the end of that chief happiness, which consists in the acquisition of such things as are according to nature. [TD, 143-144]

Gassendi, unlike Epicurus, maintains that God's providence justifies our trust in the guidance of nature, for God has artfully arranged his creation so that creatures naturally desire their own good, and are guided by their natural experience of pleasure and pain in their pursuit of that good.

The whole of Gassendi's moral philosophy, in which the moral is identified with the natural, is unified by his account of divine providence.

The Designer of Nature... seasoned all actions with the spice of pleasure; and willed the greatest pleasures for those future acts that are most necessary for the preservation of either an entire genus or for the preservation of individual animals. [G, 2.701]

From this viewpoint, what is moral and what is natural coincide, because God, as the designer of nature, is the cause of the natural inclinations and aversions, and the pleasures and pains, which combine to constitute our affections and to influence our actions. The natural is that which is in accordance with the divine plan; doing with a little is natural for human beings because a diet of only that which is necessary for health is what, in fact, in God's plan, is most conducive to human wellbeing. Nothing natural to us, i.e., nothing necessary for our well-being, can cause us pain. Pain is God's means of guiding us to avoid that which is harmful to us, that which is not natural for humans beings in the divine design. As such, acting so as to avoid pain is a moral requirement, respecting God's will.

For Gassendi, then, the natural, in regard to diet, includes all that humans can consume without ill effect, in accordance with the divine plan. The necessary is a subclass of the natural, and consists in the minimum, chosen from what is natural to human beings, that is required to maintain human health. Gassendi tells us that "Flesh seems to be no natural food for human beings." [TD, 288] According to Gassendi, eating flesh is not necessary for human wellbeing, it is not a proper element in a minimal human diet, because it is not natural for human beings-it violates the divine plan and hence can be detrimental to human health and can cause pain.

In a letter to Van Helmont written in 1729, Gassendi rejects Van Helmont's claim that meat is a natural food for human beings. He says:

From the formation of our teeth, it can be seen that we are not prepared by nature to be flesheating animals. To animals, such as lions, tigers, bears, dogs, cats, and others, which nature prepared for this nourishment, she gave long, pointed, sharp, separated, unequal teeth. On the contrary, to those that should eat herbs and fruits, nature gave teeth that are short, wide, obtuse, contiguous and disposed in a single series, as one can notice in horses, cows, sheep, deer and other creatures. Now the teeth of men are not like those of the former genus, but of this latter. 
Therefore, it is probable nature wishes us to be nourished not on meat as the prior, but on fruits as the posterior. ${ }^{10}$

Gassendi further maintains that flesh is too succulent for our bodies, and eating flesh foods overburdens the stomach, impedes digestion, and causes illness. He explains that meat must be digested wholly in the stomach rather than in the mouth; the body is overwhelmed by this substance. Nourishment by fruits does not produce this kind of effect. On the contrary, Gassendi tells us, fruits are a light nourishment. As such, they do not overburden the stomach, they are easily digested, and they form a chyle sufficient for our nourishment. That humans are by nature vegetarians is, for Gassendi, evident in the physical structure of our teeth and in our physiological reactions to what is eaten, and, in this, for Gassendi, God's will and guidance to us is clear. Further, it is his view that what is natural and what is moral coincide, and, therefore, it is imperative to act in accordance with our nature, i.e. with God's will.

Yet there can be a conflict of values in obeying God's will, and this is the case for the inhabitants of Isla. As religious Jews during the holocaust found it the lesser of evils to eat unkosher foods rather than starve, so too the human beings on Isla, in effect, in a lifeboat situation, are justified in eating flesh, but as a lesser of evils, for the sake of survival.

Gassendi explains:

[T] he first inclination that Nature has bestowed on us is self-preservation; that we may preserve ourselves such as we ought to be; that we are men made up of soul and body; and therefore according to our natural inclination, we must love these things, and make them the end of that chief happiness which consists in the acquisition of such things as are according to Nature. [TD, 143-144]

and

Every creature of whatsoever nature loves itself, or any part of itself, or the use of that part, or any of the things, which are according to nature, and its state and frame. [TD, 144]

Gassendi argues at some length that human beings, indeed all animals, have a natural and fundamental desire for self-preservation and a natural fear of death. In this context, Gassendi objects to the Stoic view that death, and therefore suicide, is no evil. The fact that, as a fundamental inclination governing all other actions, "Nature furnishes all sorts of animals with a natural love of life" [TD, 29] and a natural aversion to death provides evidence that preservation of one's life is a fundamental moral requirement. Hence, from Gassendi's viewpoint, the defense or preservation of one's life would justify a needed violation of moral requirements of sobriety, which are concerned with promoting one's own well-being. That is, that minimal diet which is necessary is, under normal circumstances a subclass of the natural, but, conditions may occur where that which is necessary for survival, the fundamental consideration, departs from what is natural. That which is requisite for preservation of one's life outweighs what is natural and necessary for well-being, so, though the human inhabitants of Isla may suffer discomforts and even risk illness by eating flesh, this is preferable to starvation.

It might be argued that Gassendi's providentialism is questionable, and, without this presupposition, his arguments provide us, at best, with self-interested health reasons for vegetarianism, but not moral reasons. One therefore might object that even if we were to grant that all flesh is detrimental to human health, itself a questionable assumption, vegetarianism would at best be a matter of prudence, not a moral requirement. To examine the force of this objection to Gassendi's account, we tum, in the following section, to Gassendi's discussion of our moral obligations to others.

\section{II}

Moral obligations to others are the fundamental consideration in Gassendi's discussion of the virtue of justice. Gassendi attributes to Epicurus the view that obligations of justice rest upon a mutual contract and so exclude relations between humans and animals. From this Epicurean viewpoint:

[T] here is no kind of right and injury, of just or unjust between the rest of animals, because it was not possible to make any agreement between them, that they should do no mischief to one another: So there ought not to be between nations which could not or would not make any such compact, to do no wrong one to another. [TD, 319] 
Gassendi also discusses moral obligations to others that fall under considerations of temperance. In discussing temperance, which encompasses virtues related to the proper regulation of desires, Gassendi considers actions which arise from the experience of other-interested affections. For example, he claims:

It is human and natural to be afflicted with those that suffer. [TD, 300]

\section{Gassendi notes:}

[It is] strange to consider how great an affection we have for those whom we read of in history to have shown themselves very kind and merciful, and how we abominate those who have been barbarous and cruel. [TD, 298]

The pleasure and pain of our natural affections, e.g., "the grief or concern that we have for another's calamity," [TD, 299] guides us towards the virtues of mercy, gentleness, and clemency. Divine providence has so arranged human nature that, for us, there are pure pleasures, which are never accompanied by pain, and stable pleasures, which as natural and necessary produce no pain or misery. Pure pleasures and stable pleasures are easy to obtain and never require causing pain to others. But, for Gassendi, are animals included among these others towards whom our action is guided by a natural empathy? It would seem so, since, in explaining the Epicurean view of our moral obligations to animals, he likens our relation to nonhuman animals to our relation to humans outside of our society and its laws. We are told:

You may perhaps here by the by ask why we kill those creatures..., which we have no reason to fear? I confess we may do this sometimes through intemperance and cruelty, as by inhumanity and barbarity we often abuse such sometimes who are out of our society, and of whom 'tis not possible that we should apprehend any danger of evil. [TD, 321]

Killing of animals that is not in self-defense is characterized as an offence "against temperance, or... [against] its species, viz., such as sobriety, gentleness, or humanity and a natural goodness." [TD, 321]
Further, we are told that it is:

Incident to a weak, cowardly and savage nature, to show cruelty to those who are overcome, nay, though they have given no particular provocation...[TD, 297]

and

Reason forbids us to be cruel against the innocent, who never did us any harm...[TD, 30]

Gratuitous cruelty to innocents, including animals, as other wrongs of intemperance, is neither natural nor necessary. It is unnatural because it violates the empathy or shared pain that is naturally raised in us by the apprehension of pain experienced by others. According to Gassendi, divine providence guarantees that nothing unnatural is necessary, and, consistently with this, he maintains that killing animals is not necessary for human well-being. It would seem that, for Gassendi, the killing of an animal as of another human being is justifiable only as an act of self-defense.

$\mathrm{He}$ further explains of all sentient beings:

Nature has made us all related and a kin, by bringing us forth from the same principles and of the same elements. 'Tis Nature hath given us a mutual affection and love, and for the same ends. 'Tis Nature hath established what is right, just and equitable to its Law. 'Tis a greater evil to be the cause of wrong than to suffer it. Nature commands that our hands should be always ready to afford assistance. [TD, 370-371]

Human beings become conscious of a natural bond with other creatures who are capable of suffering pain by the regular experience of compassion or empathy, which is raised naturally in apprehending the suffering of innocent sentient beings. The pain or suffering of other sentient beings naturally raises in us the "grief or concern that we have for another's calamity" [TD, 299], and with this, the reasoned condemnation of gratuitous cruelty. We come to view all sentient beings as a single community. From this viewpoint, to do well, we ought to treat all who are capable of suffering pain in accordance with the following revised principle of least pain: "Living well" consists in doing that which 
will be most effective in minimizing physical or mental pain in oneself and in others.

We might draw from this an implicit endorsement of a moral sense theory in which sympathy, or the pain naturally experienced in apprehending the suffering of others, leads moral agents to apprehend that causing pain in any sentient being is wrong. Animals, as capable of suffering pain, would be, from this viewpoint, regarded as moral subjects, to be treated in accordance with the principle of least pain. Once again we confront Gassendi's providentialism. God has so designed us that we naturally experience sympathy with the pain of sentient creatures. This natural experience guides us to refrain from cruelty towards all sentient creatures.

However, it might be claimed that this does not provide grounds for vegetarianism. That is, if an animal, or even a human being, is treated well and killed painlessly, why is it morally wrong to eat that creature? We have not caused any pain to an individual capable of suffering pain.

We might respond that Gassendi's view that empathetic perception of others is natural led him to regard the use of animals as food as unacceptable. That is, though, from Gassendi's viewpoint, human beings are presently misled by the acquired custom of using animals as food, the sympathy experienced in relation to sentient beings can be said to naturally motivate moral agents, not misled by custom, to refrain from using animals as food.

Further, we can argue that this account does provide some basis for vegetarianism. Indeed, if a painless death cannot be assured, and if we accept the principle of least pain applied to the community of all individuals capable of suffering pain, along with the recognition that eating flesh is not necessary for human selfpreservation, then, it would appear, that doing well under these conditions would involve not eating flesh.

Finally, the killing of animals is explicitly considered:

You may perhaps here by the by ask why we kill those creatures..., which we have no reason to fear? [TD, 321]

The killing of an innocent being that loves its life and desires its own survival is regarded as gratuitous cruelty. As indicated in the previous section, it is Gassendi's view that all sentient beings love life and have a natural desire for their own survival. He says:
Every creature of whatsoever nature loves itself, or any part of itself, or the use of that part, or any of the things, which are according to nature, and its state and frame. [TD, 144]

There is a moral requirement that moral agents act to support their own natural desire for self-preservation. Therefore Gassendi would maintain of moral agents that: It is never wrong to defend one's life by legal means where possible or by the most human means available, where legal means have no force.

This position is consistent with the presumption of a moral requirement that moral agents respect the natural desire that other creatures have for their own selfpreservation. From this viewpoint all killing that is avoidable, i.e., that is not necessary for the defense of one's life, would be morally wrong. The eating of flesh is not necessary for human well-being and so is not required for the defense of human life. Therefore, the killing of animals for food would be morally wrong. Vegetarianism would be required not solely on the prudential grounds that it is better for human health. It would be required for human beings because it is wrong for a moral agent to kill an innocent being that loves its own life. It can be argued that such action is, in Gassendi's terms, cruel, barbarous, inhumane, and therefore immoral as a violation of the virtue of temperance.

Still, if I gratuitously damage my fine crystal pitcher by smashing it with a hammer, this can be called intemperate, as a failure of proper self-control, but not thereby immoral. Acts of intemperance are character failings, violations of requirements of self-control. While an intemperate act may be seen as a failure to fulfill a moral requirement, it does not constitute a failure to fulfill a moral obligation in the strong sense. Moral wrong-doing in the strong sense, is, in Gassendi's terms, injustice. In what follows I will consider support for vegetarianism from a Gassendist viewpoint, not on grounds of temperance, as argued above, but rather on grounds of justice.

Gassendi rejects the analyses of animal cognition provided by his Cartesian and Aristotelian contemporaries. ${ }^{11}$ His analysis, to which we now turn, further supports the view that animals are moral subjects. ${ }^{12}$

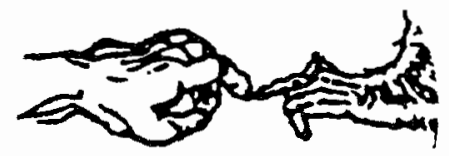


III

From Gassendi's viewpoint, animals are not moral agents. Only human beings have moral obligations because only human beings have the reflective capacities that are essential to understanding moral principles. But, I wish to claim, Gassendi's account is consistent with the view that animals are moral subjects, whose natural desire for life ought to be respected by moral agents.

Gassendi's chief adversaries, Cartesians and Aristotelians, ${ }^{13}$ rejected the view that animals are moral subjects. Cartesians maintained that animals have no moral status. ${ }^{14}$ Aristotelians, who viewed animals as property under the dominion of humans, objected to needless physical abuse of these sensitive creatures on grounds of benevolence but saw no problem with the humane killing of animals for human use. Gassendi's departure from these adversaries in his analysis of the nature of animals supports a different view of our obligations to animals. In this final section, I will consider this departure.

Gassendi explicitly objects to Descartes' view that animals cannot think. ${ }^{15}$ In the Discourse, Descartes presents the view that animals have no conscious awareness: ${ }^{16}$

This will not seem at all strange to those who know how many kinds of automatons, or moving machines, the skill of man can construct with the use of very few parts, in comparison with the great multitude of bones, muscles, nerves, arteries, veins and all the other parts that are in the body of any animal. For they will regard this body as a machine which, having been made by the hands of God, is incomparably better ordered than any machine that can be devised by man, and contains in itself movements more wonderful than those in any such machine. [AT, VI. 55-56; C, 1.139]

Descartes argues, in support of this view:

...if any such machine has the organs and outward shape of a monkey or of some other animal that lacks reason, we should have no means of knowing that they did not possess entirely the same nature as these animals; whereas if any such machines bore a resemblance to our bodies or imitated our actions as closely as possible for all practical purposes, we should still have two very certain means of recognizing that they were not real men. The first is that they could never use words, or put together other signs, as we do in order to declare our thoughts to others.... Secondly,...they [act]...not through understanding, but only from the disposition of their organs.... it is for all practical purposes impossible for a machine to have enough different organs to make it act in all the contingencies of life in the way in which our reason makes us act. [AT, VI, 56-57; C, 1.139-140]

According to Descartes, animals are seen to be irrational because they cannot use speech and they cannot use reason to freely choose how they will act. He underlines the importance of understanding the great difference between the natures of animals and humans because failing to perceive this distinction can have moral implications:

...after the error of those who deny God...there is none that leads weak minds further from the straight path of virtue than that of imagining that the souls of the beasts are of the same nature as ours, and hence that after this present life we have nothing to fear or hope for, any more than flies and ants... [AT, VI. 59-60; C, 1.141.]

Gassendi, in his objections to Descartes' Meditations, responds to Descartes' arguments. In response to the claim that animals cannot speak, Gassendi argues:

You may say they do not speak. But although they do not produce human speech (since of course they are not human beings), they still produce their own form of speech, which they employ just as we do ours. You may say that even a delirious man can still string words together to express his meaning, which even the wisest of the brutes cannot do. But surely you are not being fair if you expect the brutes to employ human language and are not prepared to consider their own kind of language. But to go into this would need a much longer discussion. [AT, VII, 271; C, 2.189] 
He says of freedom of choice in acting:

You may say that you are free and the soul has the power of preventing a man from both fleeing and advancing. But the principle of cognition does just this in the case of an animal: a dog, despite his fear of threats and blows may rush forward to grab a morsel it has seen-and a man often does just the same sort of thing! You may say that a dog barks simply from impulse, and not, as happens when a man speaks, from choice. But in the case of man, too, there are causes at work which may lead us to judge that he speaks from some impulse. What you attribute to choice occurs as a result of a stronger impulse, and indeed the brute, too, exercises choice, when one impulse is greater than another. Indeed, I have seen a dog matching his barks to the sound of a trumpet, so as to imitate all the changes in the notes, whether sharp or flat, or slow or fast. And it managed to do this even when the tempo of the notes was arbitrarily and unexpectedly speeded up, or when the notes where unexpectedly drawn out. [AT, VII, 270 ; C, 2.188-9]

He adds, considering the use of reason:

You may say that brutes lack reason. Well, of course they lack human reason, but they do not lack their own kind of reason. So it does not seem appropriate to call them 'aloga' ['irrational'] except by comparison with us or with our kind of reason; and in any case 'logos' or reason seems to be a general term, which can be attributed to them no less than the cognitive faculty or internal sense. You may say that animals do not employ rational argument. But although they do not reason so perfectly or about as many subjects as man, they still reason, and the difference seems to be merely one of degree. [AT, VII, 270-271; C, 2.189] ${ }^{17}$

Gassendi, objecting to Descartes' view of animals, maintains that animals have a capacity to think, though not all the powers of thought that human beings have. He claims that animals cannot reflect on their own mental awareness or formulate abstract ideas. ${ }^{18}$
However, animals experience sensations and, with this, pleasure and pain; they are capable of imagistic reasoning and of exercising will or choice. Hence, postulating a fundamental continuity among the whole community of animals, Gassendi suggests that the difference between the cognitive powers of humans and other animals is "merely one of degree," not kind.

In addition, Gassendi objects to the Aristotelian analysis of animal cognition, presented in his time, for example, by Suarez. Suarez argues:

\section{But Aristotle clearly writes in the Politics VII, at the end of chapter thirteen, that man alone has reason. Whereas in brute animals there is no sign, or effect, in which they show the use of reason. Hence, they have neither proper speech, nor freedom in operating, but are led by natural instinct. ${ }^{19}$}

Suarez, like Gassendi, objects to the view that animals experience no sense awareness. Speaking of those who "deny sensitivity to them," i.e., to animals, he states: "But truly, this opinion is intolerable, and a great paradox...." [S, III.500 ${ }^{20}$ According to Suarez, animals experience sensation, but they are incapable of reasoning or will. Animal activity is not the result of choice based upon thought; it is the automatic response to a stimulus determined solely by "natural instinct."

Gassendi explicitly objects to the view that animal behavior can be described as the effect of "blind instinct." Animal behavior, like human behavior, he claims, involves learning from one's experience or from one's associates, along with a rudimentary sort of reasoning. From the natural experience of pain, e.g., of hunger, and, in turn, of the pleasure involved in relieving such pains, associations are formed by the imagination [or phantasy] which serve to direct future pursuit and avoidance behavior. Gassendi says of instinct:

It is easy to understand from all this that what we call instinct is a certain motion which is not blind, but is in fact directed by the phantasy; and this, in part, by a simple apprehension of good or bad, principally when it is present, and, in part, also by reasoning, in so far as one judges of the good or bad which should follow in the future and of which one has some sort of presentiment. This motion, then, is the spontaneous use of the parts properly destined 
to act with regard to this reasoning, as the use of the feet to flee, that of the hom, tooth and the like to attack...[G, 2.415]

The pursuit and avoidance behavior of animals follows from remembering "what has succeeded and what has not succeeded in order that they infer that they ought or ought not to perform a certain action." [G, 2.415] This, Gassendi contends, involves not inborn instincts, but learning from experience and a rudimentary sort of reasoning, i.e., sense reasoning, which requires the use of images. Further:

Instructed not only by their own observations but also by teaching and examples, whether from their parents or from certain others whose actions they have seen and from whom the vestiges remain in the phantasy, they reason about what they should do. [G, 2.415]

Gassendi provides empirical evidence to support his hypothesis that the pursuit and avoidance behavior of animals is based not upon "blind instinct," but rather upon imagistic or sense reasoning from what has been experienced or from what has been learned from others. He cites examples to demonstrate that animals experience a desire for their own good and for the good of their offspring, and that they exercise imagistic reasoning to achieve their ends. Hence, according to Gassendi, animals are not to be dismissed as wholly irrational, for they act on the basis of a rudimentary sort of reasoning and will.

Therefore, Gassendi argues that the avoidance behavior of animals is motivated by fear, raised by reasoning from past to future experience, which leads to the awareness of a danger to life or limb. He claims that "most animals flee us because they have received some harm from us" [G, 2.415] and, in support of this claim, cites reports that, in wilderness areas of America, animals, which have never been hunted by human beings, have no fear of humans. Further, fear of a particular kind of creature cannot be instinctive:

It may even be that the lamb wouldn't flee the wolf if it hadn't learned to flee with the others and if it hadn't perceived the wolf coming at it with its mouth ajar. Moreover, the lamb doesn't flee the wolf it knows nor the hare the dog with whom it was raised. [G, 2.416]
An animal loves its own life and learns, from its own experience or from that of others, to fear and to avoid those things that are likely to harm it.

It is from this viewpoint that Gassendi says that "Nature fumishes all sorts of animals with a natural love of life." [TD, 29] Animals think, and they direct their own actions in the light of an interest in protecting and preserving their own lives and well-being. In this sense, animals as well as human beings have a natural desire for self-preservation.

In his discussion of justice, Gassendi explains that one of the "chief offices or general duties of justice consist(s) in hurting or doing wrong to nobody," [TD, 307] where "hurt" or "harm" is used to designate not simply pain but also any loss of something valued, for example, of life, of limb, of a loved one, of property. He notes that not all action that causes harm is moral wrong-doing, as, for example, where harm is done by accident or through ignorance. He distinguishes between an unjust action, which includes all that harms an innocent victim, and an action done unjustly, or moral wrong-doing, which Gassendi designates by the term injury.

Injury involves the intent to harm. In addition, injury is done against the will of the individual harmed:

...because it is one thing to suffer an unjust act, or to receive a damage, and another to suffer an injury, a man may willingly suffer an unjust act but not suffer an injury. For that reason Aristotle observes that we define a man who does an injury: He who hurts, knowing to whom, in what manner, and how he hurts; yet that is not sufficient, but we must add this particular, Against the will of him whom he hurts. [TD, 334]

Gassendi explains that though an individual can cause himself damage, he cannot act unjustly or do wrong to himself, because he cannot truly injure or be unjust towards himself, i.e., he cannot harm himself against his own will. Further, "no injury can be done to him who consents and approves of it," unless that consent is coerced by "some pretence," by "fair promises," flattery, or the like. [TD, 335]

Since moral wrong-doing involves intentionally causing harm to another individual against its will, to morally wrong another, the victim must be capable of exercising will. From Gassendi's viewpoint, a rock 
or plant can be damaged but cannot be treated unjustly, for, since neither can exercise will, no action can be taken against the will of either one. But, as discussed above, according to Gassendi, all animals do exercise will. All desire to avoid harm and they act to preserve their own lives and well-being. The will of an animal intentionally directed to this end can be thwarted. As such, an animal can be the victim of injustice or moral wrong-doing. ${ }^{21}$

Finally, we might note that Gassendi postulates that harm to others is a wrong-doing of justice, because justice "consists in rendering to everyone that which belongs to him." [TD, 306] He contends that it is a requirement of justice that each individual be given control over and free use of that which belongs to him without constraint or interference. Such interference, when it is intentional and against the will of the recipient, is an injury and is unjust. Gassendi explains:

This has given occasion to the lawyers to define justice, A constant and perpetual will or resolution to give or restore to everyone his right; that is to say, that which justly belongs to him. [TD, 307]

He adds "these words comprehend the function and the proper act of justice": "To render to everyone his right." [TD, 308]

A right from this viewpoint is a power to exercise one's will that ought to be recognized and respected. Gassendi equates "what belongs to everyone as his right" with "what authority, power, and command everyone has over anything." [TD, 311] Intentional infringement upon or limitation of such authority or power, without sufficient reason, is the sort of harm that is characterized by Gassendi as an injury or moral wrong-doing. Gassendi refers to one's jurisdiction over that which belongs to one by nature, including life and "the natural faculties of sensation, of imagination, of appetite, of self-motion, of preserving and nourishing oneself,..." [TD, 2.798] as animal rights. He distinguishes these animal rights from another sort of rights, e.g., to property, which are distinctly human rights because the acquiring of this sort of authority or power requires a contractual agreement. This suggests that Gassendi may have departed from the Epicurean view that animals have no rights, maintaining instead that animals have rights to the unhampered use and control of those things that naturally belong to them. That is, it is morally wrong to infringe upon the power or command over those things that naturally belong to any individual, including animals, without sufficient reason. This line of reasoning further supports vegetarianism, for, from this viewpoint, it would be morally wrong in the strong sense, i.e., on grounds of justice, to infringe upon any individual's right to life, including animals, unless this can be justified as an act of self-defense.

As stated above, for Gassendi, nothing immoral is natural to human beings. And consistent with Gassendi's claims, one might conclude, whether on grounds of temperance or justice: it is because killing creatures that love their own lives is morally wrong that God has so designed human beings that eating flesh is unnatural to them. From this viewpoint, vegetarianism would be a moral requirement, one which divine providence, by our natural empathy, our natural structure and our natural pains, guides us to note.

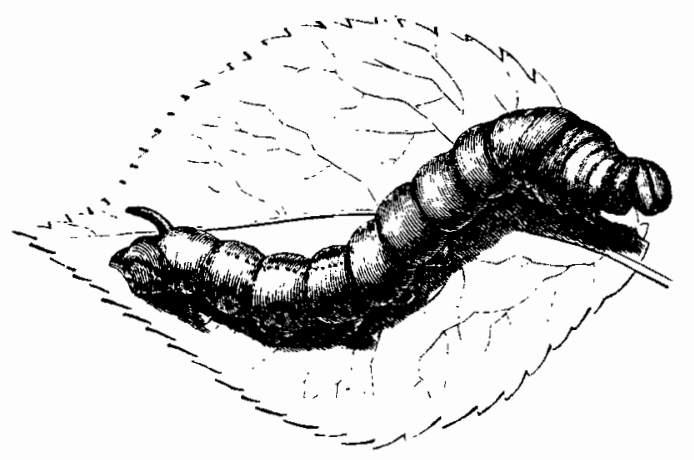

Notes

${ }^{1}$ I gratefully acknowledge that research for this paper was partially funded by a grant from the Research Foundation of the City University of New York. All translations are my own unless otherwise noted. I have modernized spelling and grammar in quotations from seventeenthcentury English texts.

${ }^{2}$ Gassendi speaks of his indebtedness to Epicurus in respect to the development of his own moral theory as early as 1624 [Exercitationum Paradoxicarum Adversus Aristoteleos..., Book I (Grenoble, 1624), preface]. Some 
selections from this work are translated into English by Craig B. Brush (ed. \& trans.), The Selected Works of Pierre Gassendi (New York: Johnson Reprint Corporation, 1972).

\begin{abstract}
${ }^{3}$ Gassendi's Epicurean Syntagma was first published as an appendix to his three volume Animadversions in Decimum Librum Diogenis Laertii (Lyons: G. Barbier, 1649). It was subsequently published separately (The Hague, 1659), then together with Gassendi's Institutio Logica (London, 1660 and 1668). See also, Thomas Stanley's 1660 English translation of Gassendi's Epicurean Syntagma, [T. Stanley, The History of Philosophy (London: Moseley and Dring, 1655-61), vol. 3, pp. 849-935]; henceforth noted as SPE. For a detailed listing of Gassendi's publications see O. R. Bloch, La Philosophie de Gassendi (The Hague: Martinus Nijhoff, 1971), pp. xxviii-xxx; and B. Rochot, Dictionary of Scientific Biography, article on Gassendi.
\end{abstract}

${ }^{4}$ For Gassendi's moral theory, see, in particular, the section on Ethic in his Syntagma Philosophicum [P. Gassendi, Opera Omnia (Lyons, 1658), vol. 2]; henceforth noted as G. This is the standard collection of Gassendi's Works. It is in six volumes. The Syntagma Philosophiae Epicuri is in volume 4.

5 Lisa T. Sarasohn, "The Ethical and Political Philosophy of Pierre Gassendi," Journal of the History of Philosophy (1982), vol. 20, pp. 239-260, responds to claims of modem scholars [e.g., Bloch, La Philosophie de Gassendi (op. cit.), pp. 376-377 and Rochot, "Gassendi: Le Philosophe" in Pierre Gassendi: Sa Vie et Son Oeuvre (Paris, 1955), p. 99] that Gassendi's ethics is not original or significant, by cogently arguing that Gassendi developed "his own profound ethical and political system" [p. 240].

6 P. Gassendi, Three Discourses of Happiness, Virtue and Liberty Collected from the Works of the Learn'd Gassendi by Monsieur Bernier (London, 1699); henceforth noted as TD. I am grateful to the Burke Library of the Union Theological Seminary in the City of New York for allowing me to study their copy of this work, This work is attributed to Gassendi and represents his Latin text quite faithfully. I will attribute quotes from this work to Gassendi. However, it should be remembered that this is a direct translation, not of Gassendi's longer section on Ethics in his Syntagma Philosophicum, but of Bernier's abridgement and French translation of Gassendi's work.

${ }^{7}$ Gassendi was very influential in seventeenth-century France and England. For evidence of the influence of his Epicurean moral theory, see, for example, E. \& F. Michael, "A Note on Gassendi in England," Notes and Queries (September, 1990), pp. 297-299. For the influence of his Epicurean physical theory, see, for example, Lynn Sumida Joy, Gassendi the Atomist, Advocate of History in an Age of
Science (Cambridge: Cambridge University Press, 1987); R. H. Kargon, Atomism in England from Hariot to Newton (Oxford: Clarendon Press, 1966), esp. ch. 8. Margaret J. Osler, considering the views of Descartes and Gassendi, argues: "In England, at least, Gassendi's views seem to have prevailed...Gassendi's mitigated skepticism and nominalist ontology became characteristic of English Science as represented in the works of Boyle and Newton. John Locke took up Gassendi's views and elaborated them in his Essay Concerning Human Understanding, which is marked by many of Gassendi's arguments, and, in places, even his language." [Osler, "Providence and Divine Will in Gassendi's Views on Scientific Knowledge," Journal of the History of Ideas (1983), vol. 44 , p. 549]. See also the seventeenth-century work by Wm. Charleton, Physiologica Epicuro-GassendoCharltoniana: a Fabrick of Science Natural upon the Hypothesis of Atoms, Founded by Epicurus, Repaired by Petrus Gassendus... (London, 1654). The Epicurean revival in Britain is the subject of T. F. Mayo's Epicurus in England (1650-1725) (Dallas: The Southwest Press, 1934), and is also discussed in A. A. Long's Hellenistic Philosophy (Berkeley: University of California Press, 1986), ch. 6.

${ }^{8}$ For another seventeenth-century English translation of the section on ethics of Gassendi's Philosophiae Epicuri Syntagma, see Walter Charleton, Epicurus's Morals (London, 1656). Of course, in the seventeenth century, many in Britain would have known these works not in English but in the original Latin or French.

${ }^{9}$ Gassendi defined moral philosophy as "the art of acting well and from virtue." [G, 2.659]

${ }^{10}$ See Gassendi's Epistolae in his Opera Omnia, vol. 6, p. 20.

11 An indication of the seventeenth-century concern with and controversy over animal cognition is clear from the following selection of seventeenth-century works: Chanet, Pierre, De l'instinct et de la connoissance des animaux avec l'examen de ce que $M$. de La Chambre a escrit sur cette matiere, La Rochelle, 1646; Cyprian, Johann, Sensus et cognito in brutis adversus Antonium Le Grand, 1676; Darmanson, Jean M., La Beste transformee en machine...que le systeme de $M$. Descartes et son opinion touchant les bestes $n$ 'ont rien de dangereux..., 1668. [English translation, $A$ Discourse... (London: Pith, 1670)]; De La Chambre, Louis, "De la connoissance des betes," Les Caracteres des Passions..., 1645, vol 2; Traite de la connoissance des Animaux..., 1647; Dilly, Antoine, De l'ame des betes... (Lyons, 1676); Le Grand, Pere Antoine, Dissertatio de carentia sensus et cognitionis in brutis (London, 1675); Pardies, Pere Ignace Gaston, S.J., Discours de la connoissance des bestes, 1672; Sennert, Daniel, De origine et natura 
animarum in brutis (Frankfurt, 1638); Willis Thomas, Two Discourses Concerning the Souls of Brutes... (London, 1672).

12 Gassendi's distinctive analysis is frequently overlooked by contemporary commentators. See, for example, the contrast of Descartes' modem view of animals as automata with the view of the seventeenth-century Peripatetics by R. M. Young ["Animal Soul," Encyclopedia of Philosophy (New York: Macmillan, 1967), vol. 1, pp. 122-127]: “Descartes's most formidable opponents in the seventeenth-century were the Peripatetics...." The Gassendist view, a view similar in many respects to the view later adopted by Locke, is attributed to Locke. Balz, in his interesting discussion in "Cartesian Doctrine and the Arimal Soul" [Cartesian Studies (New York: Columbia University Press, 1951), pp. 106-157] similarly speaks of the early seventeenth century opponents of automatism as "being in the main Scholastics" [p. 110]; Gassendi's arguments against automatism are not discussed. The view that Descartes' view of mind, body and animals was the modem view is presupposed in such articles as: $\mathrm{J}$. Jaynes, "The Problem of Animate Motion in the Seventeenth Cennury," Journal of the History of Ideas (1970), vol. 31, pp. 219-234; E. S. Reed, “Descartes' Corporeal Ideas Hypothesis and the Origin of Scientific Psychology," Review of Metaphysics (1982), vol. 35, pp. 731-752. L. C. Rosenfield [From Beast-Machine to Man-Machine (New York: Octagon Books, 1968)] presents a fairly broad perspective of seventeenth-century views in her discussion of reactions to Descartes' analysis of animals as automata.

${ }^{13}$ We find in theses written for student disputations by professors of the graduating class in the Scottish Universities, a valuable source of information about developments, concerns and influences in seventeenth-century philosophy. From the middle of the seventeenth century, these provide the consideration of three basic views, those of the Aristotelians, the Cartesians and the Epicureans. These three views have, as chief proponents, Suarez, Descartes and, popularizer of Epicurean views, Gassendi.

${ }^{14}$ Though Descartes himself was never accused of mistreating animals, many of his followers were associated with callousness and cruelty towards animals by their contemporaries. Fontaine, speaking of Descartes' followers at Arnauld's Port-Royale-des-Champs, derides the attitude of Cartesians towards animals:

"They administered beatings to dogs with perfect indifference, and made fun of those who pitied the creatures as if they had felt pain. They said that the animals were clocks; that the cries they emitted when struck were only the noise of a little spring which had been touched, but that the whole body was without feeling. They nailed poor animals up on boards by their four paws to vivisect them and see the circulation of the blood which was a great subject of conversation." [N. Fontaine, Memoires pour servir a l'histoire de Port-Royal (1738), vol. 2, pp. 52-3; translation by L. C. Rosenfield, op. cit., p. 54.]

${ }^{15}$ For Descartes' presentation of his view of animals as automata, see, for example, Descartes' discussion in his Discourse on Method [C. Adams \& P. Tannery, eds., Oevres de Descartes (Paris: 1897-1913), vol. 7, pp. 55-57; henceforth noted as AT; J. Cottingham, R. Stoothoff, and D. Murdoch, translators, The Philosophical Writings of Descartes (London: Cambridge University Press, 1985), vol. 1, pp. 139-140; henceforth noted as C.].

${ }^{16}$ For Descartes, the complete distinctness of mind and body, as a thinking and an extended substance respectively, implies that animals, as extended substances, haveno conscious awareness. Descartes explicitly states that this means that animals experience neither pleasure nor pain. See, for example, his response to Merseene, AT, III. 85, letter 192, June, 1640.

${ }^{17}$ See also, other arguments presented in support of his view of animal cognition in Gassendi's objections to Meditation II.

${ }^{18}$ For further discussion of Gassendi's arguments, see E. \& F. Michael, "Two Early Modern Concepts of Mind: Reflecting Substance vs. Thinking Substance," Journal of the History of Philosophy (1989), vol. 27, pp. $29-47$.

19 R. P. Francisci Suarez, Opera Omnia, De Anima, (L. Vives: Paris, $1856 \mathrm{ff}$.), vol. 3, p. 500; henceforth noted as S. Suarez, an influential representative of Thomistic Aristotelianism, discusses animal cognition in his DeAnima, which was published posthumously in 1620 .

${ }^{20}$ Suarez does not identify any proponents of this position. The view that animals function as automata was held before Descartes by, for example, the Spanish physician, Gomez Pereira [Antoniana-Margarita, Medina del Campo, 1554]. For discussion of Pereira, see, for example: N. A. Cortes, "Gomez Pereira y Luis de Mercado datos para su biografia," Revue Hispanique (1914), vol. 31, pp. 2-29; E. Bullon y Fernandez, Les Precursores espanoles de Bacon y Descartes (Salamanca, 1905).

${ }^{21}$ This Gassendist position is at variance with the thoroughgoing contractarian account of justice which Gassendi attributes to Epicurus. There is no evidence that Gassendi himself held the view that animals are members of a moral community, or that he recognized moral patients that are not moral subjects, but these assumptions are consistent with a Gassendist analysis of justice. 